Nikolaj V. Nikolajev

Petersburg

\title{
Wydania antwerpskiej Officina Plantiniana z kolekcji warszawskich Rosyjskiej Biblioteki Narodowej
}

Wśród osiagnnięć europejskiego drukarstwa książkowego wieków XVI i XVII bibliofile, bibliotekarze $\mathbf{i}$ antykwariusze szczególnie wyróżniają produkcję niektórych oficyn wydawniczych. Przedmiotem specjalnych badań i kolekcjonerstwa sa weneckie i rzymskie aldyny, holenderskie elzewiry, paryskie druki Etienne'a. Do tej grupy wydawców-typografów o światowej sławie należy też antwerpska firma Krzysztofa Plantina1. Pewną liczbą arcydziel wydawniczej działalności Plantina może się poszczycić Ermitaż Państwowy², zagadnienie utworzenia odrębnej kolekcji ich wydań w Rosyjskiej Bibliotece Narodowej jest do dziś aktualne. Jak pokazały już pierwsze etapy badania tego zagadnienia, znaczna część petersburskich plantinianów pochodzi z biblioteki braci Załuskich i biblioteki Warszawskiego Towarzystwa Przyjaciół Nauk, w różnych czasach włączonych w skład Cesarskiej Biblioteki Publicznej w Sankt-Petersburgu³. Nasz niewielki artykuł poświęcimy omówieniu niektórych z tych książek.

W pierwszej połowie XVI wieku Antwerpia stała się jednym z najważniejszych ośrodków, skąd wpływ kultury Renesansu rozpowszechniał się na Niderlandy. Był to jednak ośrodek bez humanistów, wpływ dokonywał się poprzez druk i handel książkami. We wczesnym okresie druku książek jako glówne centra nauki i druku wyróżniały się Deventer i Leuven. Według obliczeń Barbary Górskiej, w Antwerpii wydano 392 inkunabuły, tym samym miasto zajęło pozycję za Deventer, gdzie wydrukowano 596 inkunabulów, a przed Leuven, gdzie wydano ich 296; tylko około 30 antwerpskich inkunabułów można było uważać za wydania humanistyczne ${ }^{4}$. W tym czasie, kiedy typografowie w Deventer i Leuven pracowali głównie dla uczonych profesorów i studentów, wydawcy antwerpscy dostarczali książek bogatym przedstawicielom klasy średniej, mówiącym po

\footnotetext{
${ }^{1}$ L. Voet, The Golden Compasses. A History and Evaluation of the Printing and Publishing Activities of the Officina Plantiniana at Antverp, Vol. 1-2, Amsterdam 1969-1972.

${ }^{2}$ Музеум книги: каталог выставки Научной библиотеки Государственного Эрмитажа с 17 декабря 2002 года по 2 марта 2003 года, Санкт-Петербург 2002, s. 28-33.

${ }^{3}$ Moričeva

${ }^{4}$ B. Górska, Krzysztof Plantin i Officina Plantiniana. Wroclaw 1989, s. 247.
} 
flamandzku i nieco po francusku. Klasa ta nie zajmowała się postępem wiedzy i nauki, a jej potrzeby duchowe zaspokajały traktaty moralne i religijne, bogate ilustrowane książki, popularne dzieła literackie.

Produkcja typograficzna wymagała dość dużych inwestycji, aktywnego rynku pieniężnego i naturalnie dużego rynku zbytu. Kiedy na początku XVI wieku Antwerpia stała się jednym $\mathrm{z}$ największych centrów handlowych zachodniej Europy, handel książkowy Niderlandów zacząl się skupiać w jej murach. Wczesne wydania antwerpskie wieku XVI są podobne do wydawanych tamże inkunabułów. Koncentracja produkcji książki w mieście nad Skaldą spowodowała jej zmniejszenie w innych miastach, i antwerpscy drukarze zaczęli wytwarzać książki, będące wcześniej prerogatywą ich kolegów $z$ innych ośrodków. Po roku 1520 stale wzrastała liczba wydań autorów klasycznych i filozoficznych dzieł humanistów, a także słowników oraz traktatów historycznych, geograficznych, medycznych i botanicznych.

Tak wyglądała sytuacja, gdy francuski introligator Krzysztof Plantin osiedlił się w roku 1548 w Antwerpii, gdzie zacząl drukować w roku 1555 i na przekór trudnościom w ciągu paru lat utorował sobie drogę do pozycji najwybitniejszego typografa swojej epoki i jednego $z$ największych drukarzy wszech czasów.

Plantin przylączył się do tajnego towarzystwa „Rodzina Miłosierdzia”, założonego przez antwerpczyka Hendrika Niklaesa; w interesach był realistą i drukował wszystko, co mogło przynieść zysk, choć jego osobiste skłonności kierowały się ku temu, co mogło przynieść pożytek „chrześcijańskiej wspólnocie". W drugiej połowie XVI wieku byl tym, kim Aldo Manutio w ostatnich latach wieku XV i na początku XVI: wielkim typografem-humanistą. Wraz z pojawieniem się Plantina Antwerpia znowu stała się ośrodkiem humanizmu $z$ humanistami. Na początku kariery typograf wybrał jako swój emblemat rozwarty cyrkiel, a jako dewizę - „Labore et constancia”: „Pracą i stałością". Później stworzono więcej wariantów graficznych sygnetu firmy Plantina, zawierających te elementy. Na początku kariery Krzysztof Plantin nie zawsze wystepowal jako wydawca: niekiedy był tylko drukarzem, wydającym książę dla zleceniodawcy, jak na przykład w wypadku dzieła florentyńczyka Andrei Domenica Fiocco (zm. 1452) „Dwie księgi o rzymskich władzach” (Andreae Dominici Flocci ... De potestatibus Romanorum, lib. II. - Antverpiae, 1561). Na karcie tytulowej widnieje sygnet typografa Guglielmo Silvio, a informacja o tym, że „księga tłoczona w typografii Krzysztofa Plantina" wydrukowana jest na ostatniej karcie. Książa ta - to pierwsze wydanie znanego później typografa antwerpskiego. Prawdopodobnie Silvio, który kupił tytul „królewskiego typografa”, nie miał jeszcze własnego wyposażenia i drukował książkę u Plantina. Możemy przypuszczać, że zapłacil częścią nakładu, pozwoliwszy Plantinowi wydać drugą część $z$ jego znakiem wydawniczym (,W typografii Krzysztofa Plantina pod Zlotym Cyrklem”). W Rosyjskiej Bibliotece Narodowej znajdują się oba warianty tej książki, obydwa pochodzą $z$ warszawskiej kolekcji braci Załuskich, przewiezionej do Sankt-Petersburga na rozkaz carycy Katarzyny II. 


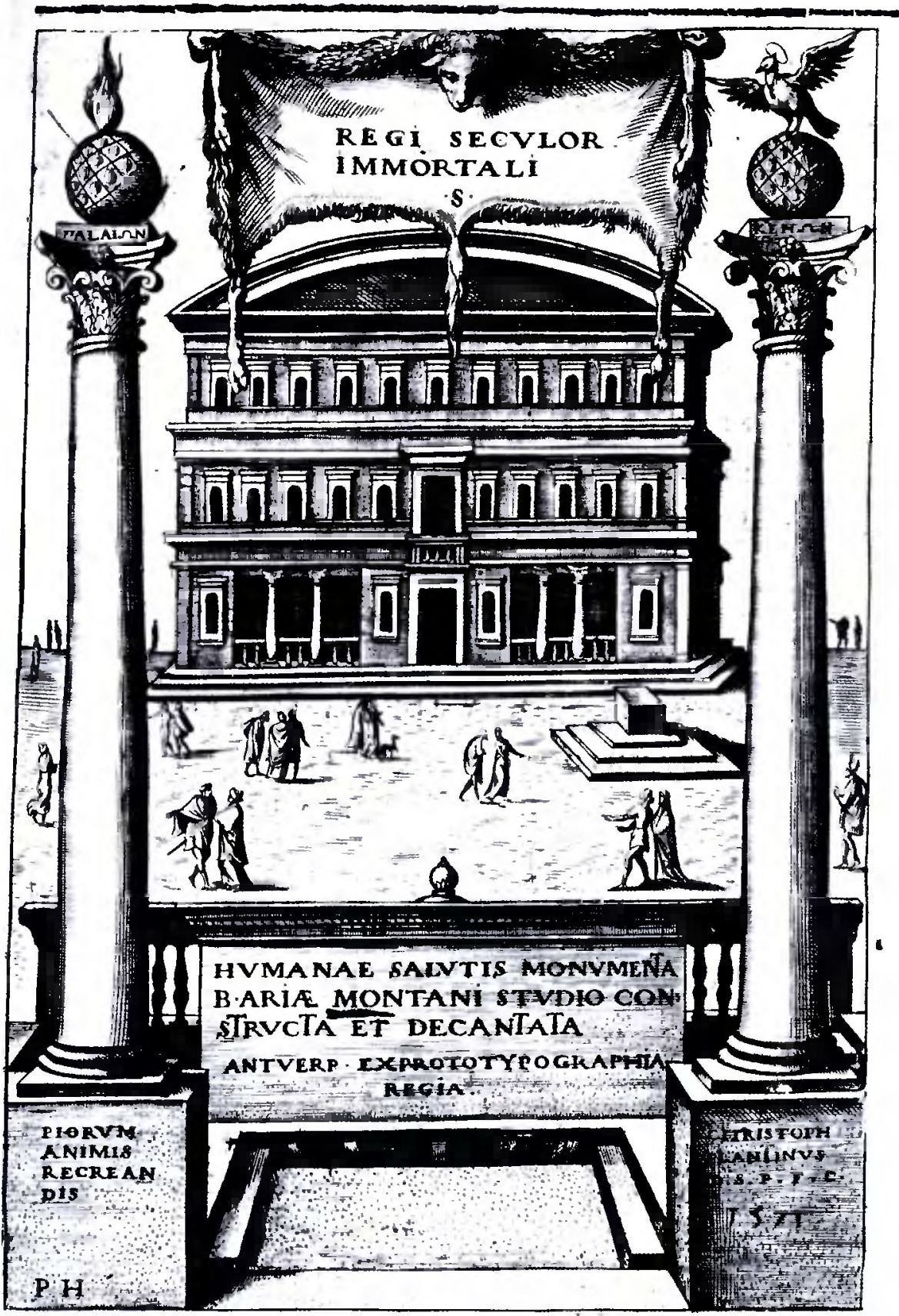

B. Arius Montanus, Humanae salutis monumentae..., Antwerpia 1571.

Z badań nad książką i księgozbiorami historycznymi, 3:2009 


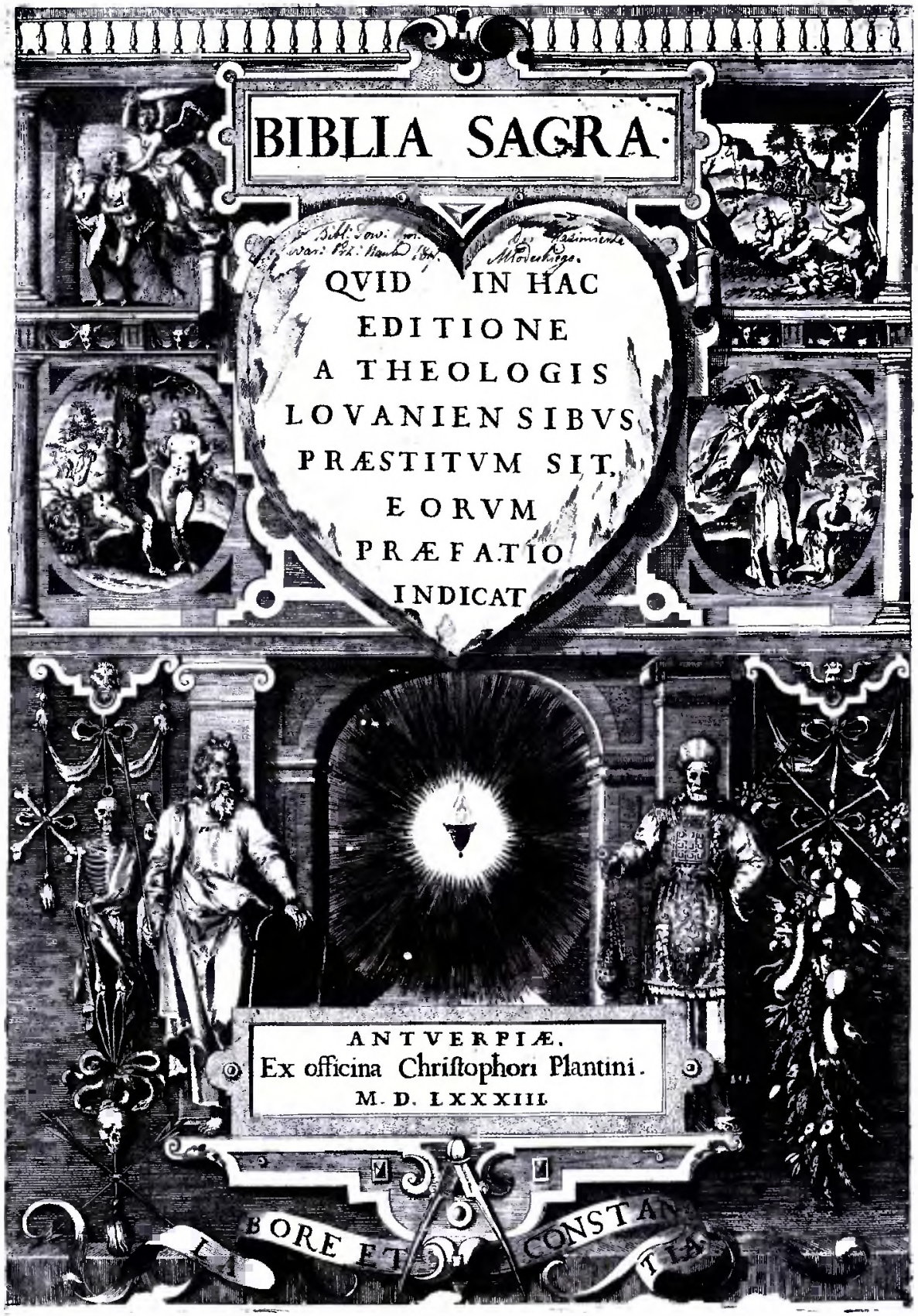

Biblia poliglotta, Antwerpia 1583. 
W ciągu dwóch lat w Antwerpii wyszła książka Tilmana Bredenbacha „Historia wojny liwońskiej, którą Wielki Kniaź Moskiewski prowadzil przeciwko Liwonii"; książkę tę królewski typograf Guglielmo Silvio drukowal już we własnej typografii.

Później Silvio stał się znanym drukarzem antwerpskim. Wydał jeden z pierwszych przewodników po mieście, w którym „dom pod Zlotym Cyrklem” (dom Plantina, kupiony w 1579, w którym mieścila się drukarnia i gdzie mieszkal typograf $z$ rodzina) określił jako jedną $z$ najbardziej godnych uwagi budowli Antwerpii.

Plantin nie mógł się poszczycić erudycją Alda Manutia czy Roberta Etienne’a, lecz mial lekkie pióro: pisal wiersze po francusku, po łacinie - przedmowy od wydawcy do niektórych swoich wydań. Wokól „domu pod Złotym Cyrklem”, wokól samego Plantina i jego dwóch uczonych zięciów, Jana Moretusa i Fransa Raphelenga skupil się krąg humanistów i uczonych. Niektórzy $z$ nich byli zwiazzani $z$ drukarnią, pracując jako korektorzy. Najbardziej znani pośród nich to Justus Lipsius i Cornelis van Kiel (łac. Kilianus), przy czym ten drugi swoimi słownikami zdobyl sławę w historii holenderskiej lingwistyki. Inni uczeni wspólpracowali $z$ typografią sporadycznie, w celu wykonania konkretnych projektów, i mieszkali wówczas w „Złotym Cyrklu”. Byli to m.in. Johann Isaac Levitt, profesor z Kolonii, który mieszkal u Plantina w latach 1563-1564, otrzymawszy oprócz kwatery i utrzymania dość znaczną sumę (70 florenów) za nowe wydanie gramatyki hebrajskiej, i Guy Le Fèvre de la Boderie, znany francuski lingwista, i jego brat Mikołaj, którzy współpracowali przy wydaniu Biblia sacra w czterech językach (tzw. Biblia królewska lub Biblia poliglotta, tomy 1-8, 156973) w językach hebrajskim, chaldejskim, greckim i łacińskim, i wielki hiszpański teolog i filozof Benito Arias Montano (1527-1598), który także po wydaniu Biblii czterojęzycznej zatrzymal się w Antwerpii na kilka lat (w RBN znajduje się sześć plantinowskich wydań jego książek, z których jedno pochodzi ze zbiorów braci Załuskich: Humanae salutis Monumenta B. Ariae Montani Studio constructa et decantata, Antverpen 1571).

Bliskie kontakty $z$ Plantinem utrzymywalo także wielu znanych obywateli Antwerpii: znakomity kartograf Abraham Ortelius, Theodor Poelman, który zarabiał na życie jako celnik, a cały czas wolny poświęcal na komentowanie i wydawanie antycznych pisarzy, rytownik Philipp Galle - glówny dostawca i wydawca miedziorytów, Jan van Gorp (Johannes Goropius Becanus), towarzysz Plantina w latach 1563-1567, lekarz i filolog-amator, który próbowal udowodnić w swoim dziele Origines Antverpianae, że Adam i Ewa w raju posługiwali się dialektem antwerpskim, niemniej jednak stworzyl podstawy współczesnej filologii porównawczej.

Królewska Biblia w ośmiu tomach nie przysłania zalet łacińskiej Biblii in folio, wydanej przez Plantina w 1583, ilustrowanej wspaniałymi rycinami, w tym skopiowaną $z$ Biblii Brzeskiej 1563 ryciną „12 pokoleń Izraela”. Antwerpski rytownik w całości zachował kompozycję brzeskiej ryciny i jej poszczególne detale, jednakże dokonał też pewnych zmian: antwerpska rycina jest nieco większa 
(240×360 mm) niż brzeska - (225×335 mm), usunięto niektóre drugoplanowe postaci, nie pokazano rzeźby terenu. Niektóre wydarzenia $z$ historii biblijnej są w Biblii z roku 1583 ilustrowane bardzo szczególowo, zwlaszcza okres pobytu Adama i Ewy w raju - dwiema rycinami, wyobrażającymi pierwszych ludzi przed grzechem pierworodnym i po nim. Egzemplarz przechowywany w RBN ma akt darowizny z 1817 roku o przekazaniu tej książki przez Kazimierza Makeckiego Warszawskiemu Towarzystwu Przyjaciół Nauk. Interesująca osobliwość egzemplarza RBN: na rycinie, przedstawiającej pierwszych rodziców przed popełnieniem grzechu, jeden $z$ pierwszych właścicieli dość wdzięcznie dorysował Adamowi i Ewie przepaski biodrowe; na drugiej rycinie (po grzechu pierworodnym) listki figowe wyobrazil już sam artysta.

Królewski arcytypograf Niderlandów Krzysztof Plantin wypuścił w świat ponad 1600 książek o najróżnorodniejszej treści. Filie jego wydawnictwa pracowały we Francji (Paryż), Hiszpanii (Salamanka), Holandii (Lejda); we Frankfurcie nad Menem Officina Plantiniana miala skład ksiazzek i stale uczestniczyła w targach książki. Wydania firmy wyróżniały się wysoką jakością poligraficzną: zawierały liczne miedzioryty i eleganckie drzeworytowe inicjaly i winiety. Jako przykład bogato ilustrowanego wydania można przytoczyć dzieło Laurentego Gambaro Brixiana „Księga świętych obiektów”, wydrukowane w 1577 roku. Ksiazzka jest ilustrowana 55 rycinami Wlocha, Bernardina Passaro (jego nazwisko wymieniono nawet na karcie tytułowej), a także niderlandzkich rytowników, Wercksa i Petra Van Der Borcha. Oprócz wierszowanych panegiryków, zwracających się do Jezusa Chrystusa i Matki Bożej, znajdują się tu utwory o charakterze świeckim, w szczególności poemat, poświęcony bitwie przeciw Turkom pod Lepanto (1571 r.), w której, jak wiadomo, stracił lewą rękę autor powieści „Przemyślny szlachcic Don Kichote $z$ Manczy”, Miguel de Cervantes. Egzemplarz należący do RBN pochodzi $z$ warszawskiej kolekcji braci Załuskich.

Po śmierci Plantina typografia w Antwerpii przeszła na własność jego zięcia, Jana Moretusa, a typografia w Lejdzie przypadła drugiemu zięciowi - Fransowi Raphelengowi. Drukarnia lejdejska w połowie XVII wieku przestała istnieć, nie wytrzymawszy konkurencji z elzevierami, a antwerpska działała jeszcze dwieście lat, wydając książki pod firmową nazwą „Officina Plantiniana” $z$ dodaniem imienia działającego zarządcy wydawnictwa. Kontynuując tradycję wydawania książek atrakcyjnych pod względem formy, spadkobiercy Plantina często stosowali miedziorytowe frontispisy, w których tworzeniu brali udzial wybitni artyści antwerpscy, do których zaliczał się przyjaciel Jana Moretusa, Peter Paul Rubens. W połowie XIX wieku wydawnictwo zakończyło działalność, w roku 1877 w domu Plantina-Moretusa w Antwerpii utworzono muzeum, a w roku 2005 muzeum zostało umieszczone na liście światowego dziedzictwa UNESCO.

„Pomieszczenia robocze” w „Zlotym Cyrklu” są przemieszane $z$ mieszkalnymi. $Z$ kuchni zwiedzający wchodzi do pokoju korektorów, stamtąd do kantoru. Z XVII-wiecznej sypialni - przejście do sali ilustracji książki, dalej do zecerni i odlewni czcionek, za którą otwiera się słynna plantinowska biblioteka, licząca ponad 30 tysięcy tomów. 


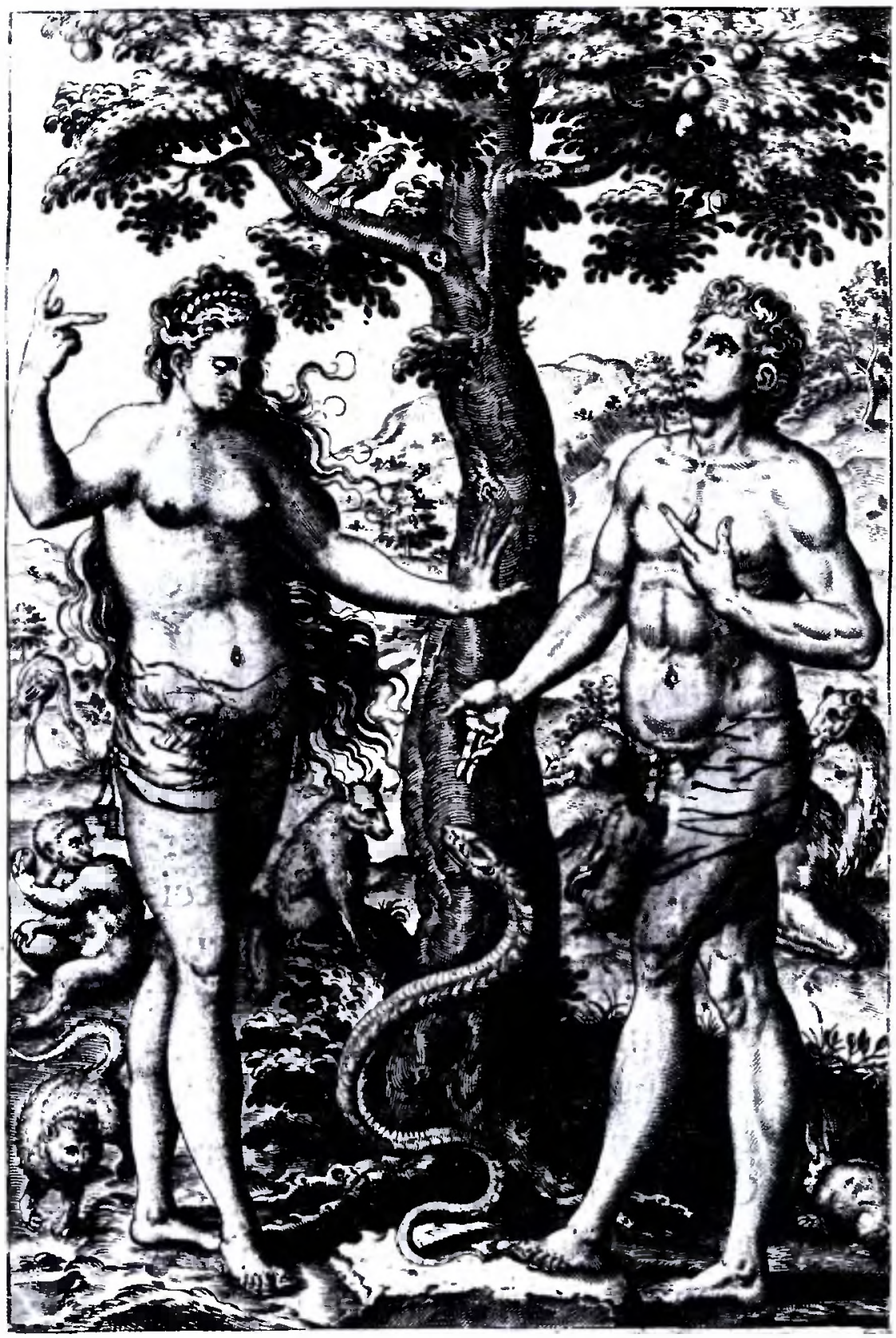

Biblia poliglotta, Antwerpia 1583.

Z badań nad książką i księgozbiorami historycznymi, 3:2009 


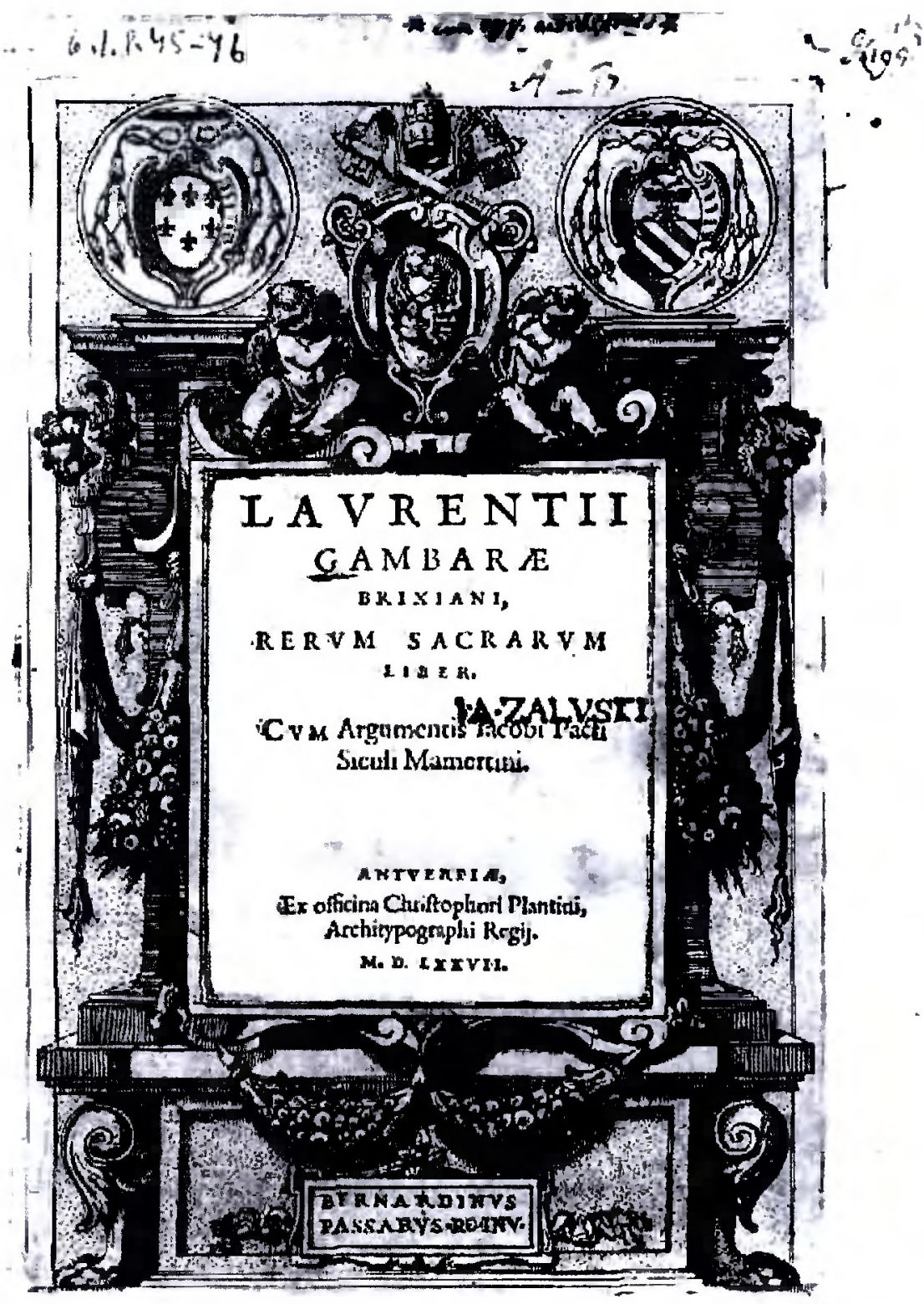

Laurentius Gambarus, Rerum sacrarum liber, Frankfurt 1577. 
W takim stanie, w jakim była za czasów Moretusów, zachowała się księgarnia, która nas przenosi w codzienność XVII wieku. Na ścianach pólki $z$ książkami, pośrodku stoi długa lada. Na ladzie - wagi do monet, odważniki. Starannie zlożone pliki poszczególnych kart - to książi, sprzedawane „in albis”, to znaczy nieoprawne. Na ścianie wisi groźny Index librorum prohibitorum, - „Spis ksiąg zakazanych", a obok - lagodny cennik podręczników szkolnych, ustanowiony przez zarząd miejski Antwerpii ${ }^{5}$. Warto zaznaczyć, że wydruko-wawszy Index librorum prohibitorum, sporządzony przez jego przyjaciela, Ariasa Montano, Plantin odkrył w „Spisie...” kilka swoich wydań, które był zmuszony wycofać ze sprzedaży i zniszczyć, $z$ niemałymi dla siebie stratami.

Wydzielenie produkcji Krzysztofa Plantina i jego następców w zbiorach Rosyjskiej Biblioteki Narodowej to zadanie bardzo ztożone. Biblioteka jest niezwykle zasobna w wydania XVI-wieczne, lecz tylko część - około 14 tysięcy tomów - znajduje się w Dziale Książki Rzadkiej, pozostałe zaś, znacznie liczniejsze, są rozproszone po całych zbiorach zagranicznych i nie mają osobnego katalogu. Jeśli chodzi o ksiażki wieków XVII i XVIII, to proporcje ich rozdzielenia między Działem Ksiązki Rzadkiej a magazynami zagranicznych zbiorów książkowych („Poligrafia” i „Rossica”), a także wyspecjalizowanymi zbiorami rycin i kartografii są do dziś nieznane, a na kartach katalogu ogólnego nie zawsze umieszczona jest informacja o wydawcy. Niemniej jednak historia tworzenia zbiorów i kolekcji narodowej książnicy Rosji pozwala uzasadnić konieczność wydzielenia „plantinianów” jako kontynuację rozwoju i organizacji zbiorów rzadkich ksiażek.

Kiedy Cesarska Biblioteka Publiczna w Sankt-Petersburgu postanowiła wydzielić $z$ podstawowego zbioru książek egzemplarze szczególnie cenne i osobliwe, mowa była przede wszystkim o inkunabułach. W roku 1857 zostały one wydzielone ze zbiorów zagranicznych i umieszczone $\mathrm{w}$ specjalnie wyposażonym pomieszczeniu, które otrzymało $-z$ powodu stylizowanych na średniowiecze pólek i mebli - nazwę „Gabinet Fausta”. Następnym etapem było przyłączenie do działu inkunabułów zbioru aldynów i elzewirów - to stało się początkiem Działu Książki Rzadkiej. Rosyjską część zbioru ozdobiły kolekcje ksiazżek, wydanych za Piotra Wielkiego oraz cyrylickie wydania $z$ wieków XVI-XVIII. Po Wielkiej Rewolucji Październikowej i przemianowaniu Cesarskiej Biblioteki Publicznej na Państwową Bibliotekę Publiczną imienia M. E. Sałtykowa-Szczedrina jeszcze przez pewien czas Dział Książi Rzadkiej rozwijał się, ale polityczna nieaktualność starodrucznych traktatów filozoficznych, prac teologicznych i religijnych ksiąg polemicznych odwróciła uwagę ogółu (to znaczy, również Dyrekcji) od „omszałych foliałów", pozostawiając ich badanie nielicznym mediewistom.

Wydania XVI w. są w ogóle mniej zbadane i opisane niż inkunabuły, bez porównania mniej jest dotyczących ich katalogów i bibliografii. W szczególności

${ }^{5}$ Por. http://www.kontorakuka.ru/countries/europe/belgium/main.htm?right=http://www.kontorakuka.ru/countries/europe/belgium/culture2.htm, zob. także: Fr. de Nave, L. Voet, Plantin-Moretus Museum. Antverp. Brussels, 1989. 
bardzo malo zbadane są kroje czcionek i ozdobniki typograficzne, co bardzo utrudnia, a w wielu wypadkach uniemożliwia określenie roku wydania i drukarza dla tych licznych jeszcze wydań, w których dane te nie są podane w samym druku.

Po ponownym utworzeniu w 2004 roku Działu Książki Rzadkiej jego pracownicy zwrócili uwagę przede wszystkim na stworzenie elektronicznego „Ewidencyjnego spisu inkunabułów”, a także na uzupełnienie i opisanie zbiorów wydań cyrylickich, w których były znaczne luki. Wznowienie prac nad wydzieleniem znaczących zabytków, znajdujących się w podstawowych zbiorach ksiązek zagranicznych - to następny etap prac nad ksiażka rzadką w RBN. Punktem wyjścia jest elektroniczny katalog wydań XVI-wiecznych, przygotowany pod kierunkiem G. R. Rider, a także poszczególne odkrycia badaczy w zbiorach książek zagranicznych. Wśród tych ostatnich znajduje się odkryte przez M. I. Tkaczenko wydanie „Officina Plantiniana” z 1612 roku (Horacii Flacci Emblemata imaginibus) $z$ autografem (rysunek piórkiem) Petera Paula Rubensa. Według przypuszczeń autora odkrycia, autograf pochodzi $z$ roku 1624, z czasu, gdy Antwerpię odwiedził król Rzeczypospolitej Władysław IV'.

Ogólem w RBN w chwili obecnej zbadano ponad 500 tytułów wydań typografii Krzysztofa Plantina, które przechowywane są w kolekcjach „Rossica”, „Poligrafia”, w Dziale Książki Rzadkiej i Dziale Kartografii. Szczególnie interesujące wśród nich są nowe wydania klasyków starożytnych oraz średniowiecznych filozofów i teologów, 26 wydań (w latach 1568-1596) podręczników etyki, filozofii. fizyki, astronomii, retoryki i gramatyki, napisanych przez humanistę Cornelisa Valeriusa (1512-1578), zbiór antwerpskich map i atlasów, a także grecka Biblia i dzieła greckich Ojców Kościoła $z$ tekstem równoległym po łacinie i po grecku. Interesujący jest adligat, zawierający pierwsze dwa tomy dziesięciotomowej edycji dzieł świętego Augustyna, wydanej przez Plantina w 1577. Marginalia na pierwszej stronie informują, że kodeks ten należał do krakowskiego klasztoru św. Michała zgromadzenia karmelitów bosych, a w roku 1817 byl nabyty dla Warszawskiego Towarzystwa Przyjaciół Nauk. Książka ma piękną oprawę, dzieło mistrzów krakowskich, $z$ wytłoczonym i złoconym imieniem pierwszego właściciela - Paulus Odensis, jego herbem i datą oprawy - 1584 r.

Interesujacy jest egzemplarz postanowień soboru trydenckiego i dekretów papieskich, wydany już po śmierci Krzysztofa Plantina „Apud Viduam \& Ioannem Moretum", w 1596 r. - na karcie tytułowej ksiażki znajduje się nie tylko zapis piórem o tym, że egzemplarz stanowi własność P. B. Sapiehy (prawdopodobnie Pawła Bernarda, który od 1704 był wielkim sekretarzem duchownym WXL, a po 1713 - biskupem żmudzkim), lecz i czerwona pieczęć lakowa $z$ herbem Sapiehów. Zapiska o tym, że książka na polecenie księcia Aleksandra Sapiehy

\footnotetext{
${ }^{6}$ М. И. Ткаченко, Рисунок с автографом П. П. Рубенса в Иностранном книжном фонде РНБ (Rysunek $\mathrm{z}$ autografem P.P. Rubensa w Zagranicznych zbiorach ksiązkowych RBN); Российская национальная библиотека и отечественная художественная культура (Rosyjska Biblioteka Narodowa i narodowa kultura malarska). nr 3, Petersburg, 2005. s. 113-127.
} 
została w 1810 roku przekazana Warszawskiemu Towarzystwu Przyjaciół Nauk znajduje się po przedmowie.

Podstawowa praca nad wydzieleniem plantinianów ze zbiorów Rosyjskiej Biblioteki Narodowej jest jeszcze sprawą przyszłości. Lecz już teraz jest oczywiste, że po przekatalogowaniu podstawowego zbioru zagranicznego znacznie zwiększy się liczba znanych egzemplarzy, a księgoznawców i historyków średniowiecza i renesansu oczekują interesujące odkrycia, związane $z$ unikatowością każdej książi, wydanej przez „Officina Plantiniana” i jej losem przed przybyciem do miasta nad Newą.

Przełożyla Aleksandra Krupina 